\title{
NOTES
}

\section{REVISITING BARTER UNDER THE CISG}

\author{
Andrew J. Horowitz*
}

As the United Nations Commission on International Trade Law (hereinafter "UNCITRAL") circulated a draft of what eventually became the United Nations Convention on Contracts for the International Sales of Goods (hereinafter "CISG"), it examined the need for uniform law with respect to barter transactions. ${ }^{1}$ At that time in 1978, various international organizations were concerned that, while barter transactions were infrequent at the domestic level, such transactions carried growing importance in international trade. ${ }^{2,3}$

In 1979, the UNCITRAL Secretariat responded by issuing a report saying that, while true barter remained relatively rare in international transactions, barter-like transactions had become increasingly common. ${ }^{4}$ However, the report concluded that it was unnecessary to create a uniform legal framework specifically for barter $^{5}$ and that, with careful drafting, the then-draft CISG could be applied to complex barter-like transactions. ${ }^{6}$

\footnotetext{
* J.D. candidate, University of Pittsburgh School of Law, 2011; B.A., Trinity College, 2006. With thanks to Professors Harry Flechtner and Ronald Brand for their advice.

1. U.N. Secretariat, Note by the Secretariat: International Barter or Exchange, 190, 9 Y.B. Comm'n on Int'L. Trade L., U.N. Doc. A/CN.9/SER.A/1978 (1978).

2. Id.

3. At that time, barter was common in transactions involving nations with non-market economies because these countries lacked hard currency necessary for monetary purchases. See, e.g., Dan Morgan, Airline Barter Deal Helps Yugoslavs, Wash. Post, Mar. 6, 1970, at A21. See infra for more discussion of this and the modern importance of barter.

4. U.N. Secretary-General, Report of the Secretary-General: Barter or Exchange in International Trade, 37, 10 Y.B. Comm'N on InT'L. Trade L., U.N. Doc. A/CN.9/SER.A/1979 (1979).

5. Id.

6. Id. at 38 .
} 
Yet, many commentators claim that the CISG was not intended to apply to barter and barter-like transactions and that it lacks the necessary elements to do so. ${ }^{7}$ Others take the view that barter is not excluded by the CISG and that it can govern barter and barter-like transactions with some careful drafting. ${ }^{8}$ Published jurisprudence is limited in this area, but there are cases supporting both positions. ${ }^{9}$

This paper argues for the application of the CISG to barter and barter-like transactions. First, this paper defines barter and examines the issue of the definition of price under the CISG and how this creates an ambiguity with respect to barter contracts. Next, it demonstrates how the CISG can be applied to barter using the reciprocal contract doctrine. It then refutes the common argument that the CISG lacks the necessary technical elements to govern barter. A discussion follows that explains how disagreement on this topic is often the result of domestic law. Last, it discusses the importance of barter to international trade, justifying the application of the CISG to barter contracts.

\section{WHAT IS BARTER?}

In its simplest form, barter is the exchange of one commodity for another without the use of money. ${ }^{10}$ For example, if a farmer needs tomato seeds, he

7. See, e.g., Franco Ferrari, The CISG's Sphere of Application: Articles 1-3 and 10, in THE DRAFT Uncitral Digest and Beyond 21, 63-64 (Franco Ferrari, Harry Flechtner \& Ronald A. Brand eds., 2004); Peter Winship, The Scope of the Vienna Convention on International Sales Contracts, in International Sales: The United Nations Convention on Contracts For the International Sale OF Goods 1-1 (Nina M. Galston \& Hans Smit eds., 1984).

8. See, e.g., John O. Honnold, Uniform Law for International Sales Under the 1980 United Nations Convention 53 (3d ed. 1999); Fritz Enderlein \& Dietrich Maskow, International Sales Law 27 (1992); Deitrich Maskow, Article 53, in Commentary on the International Sales LaW: The 1980 Vienna Sales Convention 383, 386-87 (C.M. Bianca \& M.J. Bonell eds., 1987); Michael Bridge, The International Sale of Goods 520 (2d ed. 2007).

9. See, e.g., cases supporting the application of the CISG: CLOUT Case No. 467, [Arbitration Tribunal of Russian Federation Chamber of Commerce and Industry, Russia, 11 Sept. 1998], § 3.2, available at http://cisgw3.law.pace.edu/cases/980911r1.html; [China International Economic and Trade Arbitration Commission China, 13 June 1989], available at http://cisgw3.law.pace.edu/cases/ 890613c1.html; [Tribunal of International Commercial Arbitration at the Ukrainian Chamber of Commerce \& Trade Ukraine, 15 Apr. 2004], available at http://cisgw3.law.pace.edu/cases/040415u5.html; [Tribunal of International Commercial Arbitration at the Russian Federation Chamber of Commerce and Industry Russia, 17 June 2004], available at http://www.cisg.law.pace.edu/cisg/wais/db/cases2/040617r1.html.

Cases opposed: [Tribunal of International Commercial Arbitration at the Russian Federation Chamber of Commerce and Industry Russia, 9 Mar. 2004], available at http://cisgw3.law.pace.edu/cases/ 040309r1.html; [Federal Arbitration Court for the Moscow Region Russia, 26 May 2003], available at http://cisgw3.law.pace.edu/cases/030526r1.html.

10. Black's Law Dictionary 171 (9th ed. 2009). 
might find someone who is willing to trade him the seeds in exchange for broccoli instead of paying with money. This would allow him to get the goods he needs in exchange for the goods he has available without the need for money.

Generally, when barter occurs in international trade, it is more complex than the trade of one good for another. ${ }^{11}$ It can involve trades of services, or partial barter, where a good is exchanged for another good plus some money. ${ }^{12}$ More important are complex and varied barter-like transactions where performance occurs over a long period of time. Examples cited in the 1979 UNCITRAL report include the construction of a plant in exchange for a portion of the plant's output, licensing of intellectual property in exchange for a portion of the goods produced under the license, and agreements by a manufacturer to purchase materials from the buyer of the finished product. ${ }^{13}$ These transactions are motivated by a desire to mitigate risk by assuring sources of materials or demand and reduce costs..$^{14}$ Also, a factor is countertrade transactions, where barter is used to keep the balance of trade between countries level. ${ }^{15}$ While pure barter is relatively rare in the international arena, ${ }^{16}$ this paper explores the applicability of CISG principles to pure barter, which can then be extrapolated to the more complex arrangements commonly implicated in international trade.

\section{Price Need Not Be Defined in Strictly Monetary Terms}

Though CISG Article 53 requires the buyer to pay the price for the goods, ${ }^{17}$ the word "price" is not defined by the Convention. Thus, there is ambiguity as to whether or not a price must be monetary. This for many commentators $^{18}$ is the crux of the question of whether the CISG can be applied to barter, because, in a barter transaction, the price paid for the delivery of something is the reciprocal delivery of something else.

In common English, "price" can refer to either monetary or non-monetary consideration. Merriam-Webster's Dictionary defines price as being either

11. See Report of the Secretary-General, supra note 4, at 37.

12. Id.

13. $I d$.

14. $I d$.

15. Black's Law Dictionary 403 (9th ed. 2009).

16. See Report of the Secretary-General, supra note 4, at 37.

17. United Nations Convention on Contracts for the International Sale of Goods art. 53, U.N. Doc. A/CONF.97/18, Annex 1 (Apr. 11, 1980) [hereinafter CISG].

18. See, e.g., Ferrari, supra note 7. 
"the quantity of one thing that is exchanged or demanded in barter or sale for another ... [or] the amount of money given or set as consideration for the sale of a specified thing." ${ }^{\prime 9}$ In American legal usage, "price" is also inclusive of non-monetary consideration: Black's Law Dictionary defines price as "the amount of money or other consideration asked for or given in exchange for something else; the cost at which something is bought or sold." ${ }^{20}$

Commentators who oppose the application of the CISG to barter transactions often base their opposition in defining "price" in Article 53 as being monetary. For example, Franco Ferrari claims that arguments for the application of the CISG to barter transactions neglect to "give due consideration to Article 53 [of the] CISG which expressly mentions the buyer's obligation to 'pay the price', i.e. an element the lack of which characterizes a barter transaction." ${ }^{21}$ The non-monetary nature of pure barter transactions appears to be the driving force for Ferrari's rejection of the application of the CISG. He states that the CISG does not apply to barter transactions where the entire price is paid in goods. ${ }^{22}$ Where the buyer makes part of the payment in money, however, the CISG might be applicable depending upon whether the amount to be paid is greater than the value of the goods exchanged and whether the parties intended to enter into a sales contract rather than a counter-trade transaction. ${ }^{23}$ This view is supported by a Russian case where the tribunal declined to apply the CISG because the barter contract in question involved the exchange of goods without any monetary payment. ${ }^{24}$ The tribunal also stated that, for this reason, the contract in question was not a purchase contract. ${ }^{25}$ While this argument is structured logically, it fails because neither Ferrari nor the Russian tribunal offers justification for their exclusive definition of the word "price." Rather, Honnold argues that in leaving "price" undefined, the drafters of the CISG implicitly endorsed its application to barter transactions. ${ }^{26}$ Thus, it seems incongruous to exclude barter transactions merely because of the buyer's Article 53 obligation to "pay the price."

19. Price-Definition and More from the Free Merriam-Webster Dictionary, http://www.merriamwebster.com/dictionary/price (last visited Mar. 26, 2010).

20. Black's Law Dictionary 1308 (9th ed. 2009) (emphasis added).

21. Ferrari, supra note 7, at 64.

22. Id. at 63 .

23. Id. at 64 .

24. Tribunal of International Commercial Arbitration at the Russian Federation Chamber of Commerce and Industry Russia, 9 Mar. 2004, available at http://cisgw3.law.pace.edu/cases/040309r1.html.

25. Id.

26. HonNOLD, supra note 8 . 


\section{The Reciprocal Contract Doctrine: Applying Sales Law TO BARTER TRANSACTIONS}

The argument that the CISG can practically be applied to barter transactions relies upon the reciprocal contract doctrine: that two contracts exist as consideration for each other. Thus, the seller in one contract is reciprocally the buyer in the other contract. In the first contract, party A (the seller) agrees to sell good A to party B (the buyer) in exchange for the delivery of good B. In the second contract, party B (now the seller) agrees to sell good $\mathrm{B}$ to party A (now the buyer) in exchange for the delivery of good A.

U.C.C. 2-304 illustrates this doctrine, stating that if the price "is payable in whole or in part in goods each party is a seller of the goods which he is to transfer." 27 This is exemplified in Commonwealth Edison Co. v. Allied Chemical Nuclear Products, Inc. ${ }^{28}$ Commonwealth Edison agreed to purchase nuclear fissile material from Allied Chemical in exchange for Allied Chemical taking and reprocessing Commonwealth Edison's irradiated fuel. ${ }^{29}$ When a dispute arose, the court ruled that the traded-in irradiated fuel was not merely part of the purchase price for the fissile material, but rather it was a reciprocal good purchased by Allied Chemical from Commonwealth Edison. ${ }^{30}$ Thus, for the purposes of determining the rights of the parties, Allied Chemical was the buyer of the traded-in fuel, and Commonwealth Edison was the seller. ${ }^{31}$ The court then proceeded to award seller's damages to Commonwealth Edison. ${ }^{32}$

\section{Reciprocal Contracts and the CISG}

Though the CISG does not specifically enumerate the reciprocal contract doctrine, it can be implied so long as "price" under CISG Article 53 is interpreted as being nonmonetary, as the price paid under Article 53 in a reciprocal contract situation is the delivery of something under another contract. As this paper demonstrates infra, once the reciprocal contract doctrine is implied into the CISG, its provisions can very easily be applied to

27. U.C.C. § 2-304 (1977).

28. Commonwealth Edison Co. v. Allied Chemical Nuclear Products, Inc., 684 F. Supp. 1429, 1431 (N.D. Ill. 1988).

29. $I d$.

30. Id.

31. Id.

32. Id. at $1431-33$. 
barter transactions. Furthermore, in the 1979 UNCITRAL report, the secretariat explains that barter-like transactions could be conducted under the CISG using reciprocal contracts, though it did suggest a scheme under which prices would be described in monetary terms. ${ }^{33}$

The reciprocal contract theory has been applied to barter transactions under the CISG. In a Russian case involving the non-delivery of goods to a Hungarian party by a Russian party after the Hungarian party had already delivered reciprocal goods, the tribunal applied reciprocal contract theory to rule on the case. ${ }^{34}$ The tribunal treated the Hungarian party as the buyer of the undelivered Russian goods ${ }^{35}$ and awarded buyer's damages under CISG Article 45(1)(b). ${ }^{36}$

In a Chinese case, the court explicitly recognized the reciprocal contracts that formed a barter transaction under the CISG in a case concerning the trade of Sesame by a Chinese party to a Jordanian party for urea. ${ }^{37}$ In a Ukrainian barter case, the court applied the CISG and awarded monetary damages based on the market value of the goods not delivered, implicitly applying the reciprocal contract doctrine. ${ }^{38}$ In another Russian barter case involving a Cypriot party, the tribunal explicitly applied the reciprocal contract doctrine and awarded monetary damages based on the value of the non-delivered goods as well as damages for interest and lost profits. ${ }^{39}$ While published jurisprudence is unfortunately limited in this area, we can see that a reasonable judicial precedent exists for implying the reciprocal contract doctrine into the CISG to govern barter transactions.

Distinguished commentators also support this view. Enderlein and Maskow suggest that the reciprocal contract theory should be used to apply the CISG to linked operations including counter-purchase, buyback, and barter. ${ }^{40}$ Further, they suggest that ambiguities concerning performance and

33. See Report of the Secretary-General, supra note 4, at 37-38.

34. CLOUT Case No. 467 [Arbitration Tribunal of Russian Federation Chamber of Commerce and Industry, Russia, 11 Sept. 1998], available at http://cisgw3.law.pace.edu/cases/980911r1.html.

35. Id. at $\S 2$.

36. Id. at $\S 3.7$.

37. China International Economic and Trade Arbitration Commission China, 13 June 1989, available at $\mathrm{http}: / / \mathrm{cisgw} 3$.law.pace.edu/cases/890613c1.html.

38. Tribunal of International Commercial Arbitration at the Ukrainian Chamber of Commerce \& Trade Ukraine, 15 Apr. 2004, available at http://cisgw3.law.pace.edu/cases/040415u5.html.

39. Tribunal of International Commercial Arbitration at the Russian Federation Chamber of Commerce and Industry Russia, 17 June 2004, available at http://www.cisg.law.pace.edu/cisg/wais/db/ cases2/040617r1.html.

40. ENDERLEIN \& MASKow, supra note 8; Maskow, supra note 8. 
counter performance can be resolved through careful drafting. ${ }^{41}$ Bridge sees "no reason ... to exclude the CISG if the two supplies of goods can sensibly be rationalized as back to back sales with a set-off of the two prices due to each supplier." ${ }^{42}$ Thus, the application of the reciprocal contract doctrine to the CISG enjoys strong, albeit not universal, support amongst tribunals and commentators.

\section{The CiSG Has the Elements Necessary to Govern Barter TRANSACTIONS}

Opposition to the application of the CISG to barter often stems from a belief that the CISG does not contain the necessary technical elements to effectively govern barter transactions. This is generally based upon the 1979 UNCITRAL report, which suggests that there might be some gaps in the CISG that would frustrate its application to barter transactions. ${ }^{43}$ Winship, for example, cites this report in claiming that the CISG lacks the requisite elements to govern barter transactions. ${ }^{44}$ Additionally, while not citing the UNCITRAL report, a Russian case declined to apply the CISG to a barter transaction because "the text of the CISG gives no ground for concluding that its provisions govern . . . barter transactions" and that "due to the existing peculiarities of such [barter] transactions, not every provision of the Convention could be applied to them." ${ }^{45}$

The practical issues concerning applying the CISG to barter transactions are not insurmountable. The main problem referred to when UNCITRAL studied the issue of barter transactions during the drafting of the CISG was remedies. ${ }^{46}$ Specifically, the 1979 UNCITRAL report cites the seller's right to make the tender of delivery conditional upon the buyer's payment of the price under CISG Article $58 .^{47}$ The report contemplates difficulties in deciding when failure to perform is serious enough to justify nonperformance by the other party, when remedies are required because nonperformance is insufficient, and when a party may conclude that the other party is unable to

\footnotetext{
41. ENDERLEIN \& MASKOW, supra note 8 .

42. BRIDGE, supra note 8 .

43. See Report of the Secretary-General, supra note 4, at 38.

44. See, e.g., Winship, supra note 7, at 1-1 n.49.

45. Federal Arbitration Court for the Moscow Region Russia, 26 May 2003, available at http://cisgw3.law.pace.edu/cases/030526r1.html.

46. See Note by the Secretariat, supra note 1, at 191.

47. See Report of the Secretary-General, supra note 4, at 38. The report refers to this provision as Article 54; however it has been restyled as Article 58 since the 1979 publishing of this report.
} 
perform due to a change in creditworthiness or conduct in preparing to perform. ${ }^{48}$ It is important to understand; however, that the report does not say that these difficulties render the CISG inapplicable to barter, rather that due to the complexity of barter-like transactions, adjudicating these issues will be more difficult and that parties would be wise to preempt difficulties through careful drafting, especially in defining what constitutes a fundamental breach. ${ }^{49}$

This paper illustrates how the CISG can be applied to some of these situations using the reciprocal contract doctrine. Recall that under that doctrine, each party is buyer and seller. For the purposes of resolving these issues, it is most productive to focus on each party's role as a seller. This helps to avoid issues concerning the buyer's obligation to pay the price and results in more appropriate remedies.

\section{Remedies in Situations of Part Performance}

One of the main issues introduced in the 1979 UNCITRAL report is the question of remedies, especially in the area of damages for part performance. ${ }^{50}$ The concern appears to be that the CISG does not have the elements necessary to govern situations where one party wants to reduce the price under CISG article $50,{ }^{51}$ or is seeking damages for nonperformance. For example, a German party contracts to sell sausage to an American party in exchange for chickens. But then the deal goes sour when the chickens that arrive are not of the grade contracted for, and the German party refuses to ship the final shipment of sausage. Absent prior agreement, how would this problem be addressed under the CISG?

This situation can be dealt with under existing CISG principles using the basic premise that all goods have monetary value $\mathrm{e}^{52}$ and reciprocal contract principles. First, the court would have to determine the fair market value of the sausage and chickens as contracted for. It is immaterial that these values

\section{Id.}

49. $I d$.

50. Id.

51. CISG art. 50 (allows the buyer to reduce the price of nonconforming goods, regardless of whether the price has already been paid, in proportion to the reduction in value caused by the nonconformity, subject to the seller's right to cure. Since order of performance is a non-issue, this is not affected by confusion over who is the buyer and who is the seller in a barter transaction.).

52. CISG Article 55 allows that when the price is ambiguous, parties are "determined to have impliedly made reference to the price generally charged at the time of the conclusion of the contract for such goods sold under comparable circumstances in the trade concerned." CISG art. 55. 
might not be equal because the CISG affirms in Article 75 that damages should allow a party to recover the benefit of his bargain in the event a contract is avoided. ${ }^{53}$ Then, the court should determine the value of each party's partial performance, and determine the money damages due to each side for the breach of the other party as though they were two separate contracts. In doing this, the court would be best advised to treat both parties as breaching sellers. That is, the American party is in breach for not delivering the quality of chickens contracted for and the German party is in breach for failure to deliver the sausage and each party can claim damages for breach by the seller under CISG Article $45 .^{54}$ This is preferable to treating the parties as buyers in breach for failure to pay since it avoids issues relating to the buyer's obligation to pay the price under Article 53.

A potential ambiguity arises in determining when each party's obligation to perform is triggered under CISG Article $58,{ }^{55}$ which obligates the buyer to make payment when the seller places the goods or documents controlling the goods at the buyer's disposal and allows the seller to make tender of delivery conditional upon the buyer's payment. ${ }^{56}$ In our example with the sausage and the chicken, it would be unclear as to which party is buyer and which is seller for the purposes of Article 58 thus creating an ambiguity as to which party must perform first to trigger the other party's obligation to perform. The easiest solution is for the parties to draft order of performance into their agreement as suggested by Enderlein and Maskow. ${ }^{57}$ Because of the phrase, "If the buyer is not bound to pay the price at any other specific time," ${ }^{58}$ Article 58(1) only applies in the absence of agreement to the contrary. ${ }^{59}$

An alternative reading might be that performance by either party triggers the other party's obligation to perform, since the seller's performance triggers the buyer's obligation to pay the price, ${ }^{60}$ and price is defined in a barter contract as being the obligation to deliver on another contract under the reciprocal contract theory, where each party is the seller of the goods he is to deliver.

53. CISG art. 75 (allowing a party to recover the difference between the contract price and the price of substitute goods).

54. CISG art. 45.

55. ENDERLEIN \& MASKOW, supra note 8 .

56. CISG art. 58(1).

57. ENDERLEIN \& MASKOW, supra note 8.

58. CISG art. 58(1).

59. Guide to CISG Article 58, http://www.cisg.law.pace.edu/cisg/text/secomm/secomm-58.html (last visited Mar. 26, 2010).

60. CISG art. 58(1). 
The problem of whom is obligated to perform first remains if neither party performs. Using our sausage-chicken hypothetical, an example of the problem this could create is if the German party refuses to deliver the sausage, causing the American party to refuse to deliver the chicken, which spoils in a warehouse as a result. Theoretically, both parties would be liable for damages for breach if neither performs ${ }^{61}$ provided that neither party was excused because of an impediment outside his control under Article 79. ${ }^{62}$ Still, in this particular situation, it would seem that the American party should not be able to collect damages for losses caused by its own failure to perform, since it could have delivered the chicken, triggering the German party's Article 58(1) obligation to deliver the sausage. A court could potentially deny damages to the American party under the principle of mitigation of damages ${ }^{63}$ unless the American party believed that the German party was unable to perform. ${ }^{64}$ The potential for a party to be denied damages for failure to mitigate would create sufficient incentive for parties to perform thereby activating the other party's obligation to perform. Thus, though there is an internal gap in the CISG as to who must perform first in a barter transaction, it is unlikely to pose a substantial problem even if the parties fail to draft order of performance into their agreement.

\section{The Problem of Interest on Refunds under CISG Article 84}

CISG Article 84(1) binds the seller to pay the buyer interest if he is required to refund the price paid by the buyer. ${ }^{65}$ While interest has been awarded in barter transactions, ${ }^{66}$ it is problematic because the price paid by the buyer is the delivery of a good. It would be fairly simple to determine interest based on the monetary value of the goods, but this would not effectively serve the policy objectives of Article 84 . According to the Secretariat Commentary, Article 84 "reflects the principle that a party who is required to refund the price or return the goods because the contract has been avoided ... must

61. CISG art. 61(a)(b) (allows the seller to claim damages if the buyer does not perform his obligations under the contract. Since under reciprocal contract doctrine, both parties are sellers, both could claim such damages).

62. CISG art. 79.

63. CISG art. 77.

64. CISG art. 71.

65. CISG art. 84(1).

66. See, e.g., Tribunal of International Commercial Arbitration at the Russian Federation Chamber of Commerce and Industry Russia, 17 June 2004, available at http://www.cisg.law.pace.edu/cisg/wais/ $\mathrm{db} /$ cases $2 / 040617 \mathrm{r} 1 . \mathrm{html}$. 
account for any benefit which he has received by virtue of having had possession of the money or goods." ${ }^{67}$ In the case of a seller holding the buyer's money, the benefit he derived from the money is the use of the money during the time that he held it, and it makes sense under the policy objectives of Article 84 that he must return that benefit in the form of interest. But this makes little sense in the case of a seller holding the buyer's payment in goods. Instead of viewing this party as a seller, it is best to treat him as a buyer who is returning goods and thus obligated to compensate the other party for any benefit he derived from holding the goods under Article 84(2). ${ }^{68}$ This best meets the objectives of Article 84 in accounting "for any benefit which he has received by virtue of having had possession of the money or goods." ${ }^{\circ 9}$

\section{Positions on the Application of the CISG to Barter Transactions are Often Influenced by the Commentator's Home Legal Culture}

In analyzing this issue, we cannot ignore the effect that a court or commentator's home legal culture has on its analysis of the CISG. Indeed, there is a disturbing "homeward trend" for courts around the world to interpret the CISG through the lens of their own domestic law rather than existing CISG jurisprudence from other countries. ${ }^{70}$ Professor Honnold blames this on judges being intimately familiar with their domestic legal principles, which they are conditioned to believe are fair and make rational sense. ${ }^{71}$ The consequence is detriment to the uniformity that the CISG seeks to achieve.

In our situation concerning the definition of "price," the homeward trend is potentially complicated by the fact that the CISG is published in six official languages: Arabic, Chinese, English, French, Russian, and Spanish. ${ }^{72}$ Under Article 101 of the CISG, each of the six texts are considered to be a "single original" and "equally authentic."

67. Guide to CISG Article 84, http://www.cisg.law.pace.edu/cisg/text/secomm/secomm-84.html (last visited Mar. 26, 2010).

68. CISG art. 84(2).

69. Guide to CISG Article 84, supra note 67.

70. Harry M. Flechtner, The Several Texts of the CISG in a Decentralized System: Observations on Translations, Reservations and other Challenges to the Uniformity Principle in Article 7(1), 17 J.L. \& Com. 187, 200 (1998) (quoting John O. HonnOld, Documentary History OF THE Uniform LaW For INTERNATIONAL SALES 1 (1989)).

71. Id.

72. CISG art. 101.

73. Id. 
governed by the CISG is potentially colored not only by the definition of "price" in English, but also by linguistic nuances in five other languages.

Furthermore, commentators and courts around the world often base their answers to the question of whether the CISG applies to barter on their local law. While barter transactions are treated as sales under the U.C.C. ${ }^{74}$ the French Civil Code, upon which much of European law is based, establishes a dichotomy between sales and exchanges as distinct entities, which are governed by separate titles of the Civil Code. ${ }^{75}$ Even so, the Civil Code analogizes exchanges to sales, applying the title concerning sales to all but a few issues concerning exchanges. ${ }^{76}$ The 1978 UNCITRAL report cites this provision in claiming that "in general, civil law systems provide expressly that the provisions on sale apply, by analogy, also to barter." 77 But the barterspecific provisions concerning remedies in the Civil Code concern the exact issues that commentators point to when claiming that the CISG lacks the necessary elements to govern barter transactions. ${ }^{78}$ Thus, while American commentators generally support the application of the CISG to barter, ${ }^{79}$ commentators from civil law jurisdictions are divided. ${ }^{80}$

Additionally, the semantic difference between sales and exchanges under civil law has been exacerbated by adaptations of the French Civil Code in various countries. While the French Civil Code defines a "sale" as "an agreement by which one person binds himself to deliver a thing, and another to pay for it," contract whereby the seller undertakes to transfer to the buyer the ownership of a thing or any other proprietary right in consideration of a price in money." 82 By using the word "money," the Egyptian adaptation of the code explicitly excludes barter transactions from sales. Thus, Egyptian Commentators reject the application of the CISG to barter. ${ }^{83}$ Similarly, while

74. U.C.C. § 2-304 (2008).

75. See Sales: Code Civil [C. Civ.] arts. 1582-1701 (Fr.); Exchanges: C. Civ. arts. 1702-1707 (Fr.), translated at http://195.83.177.9/code/liste.phtml?lang=uk\&c=22.

76. C. CIV. art. 1707 (Fr.) ("All the other rules laid down for contracts of sale shall apply to exchanges as to other issues.").

77. See Note by the Secretariat, supra note 1, at 190.

78. See Report of the Secretary-General, supra note 4, at 38.

79. See, e.g., HonNold, supra note 8.

80. See, e.g., Ferrari, supra note 7 (against); ENDERLEIN \& MASKow, supra note 8 (for).

81. C. CIv. art. 1582 (Fr.).

82. Hossam A. El-Saghir, The Interpretation of the CISG in the Arab World, in CISG Methodology 355 n.44 (André Janssen \& Olaf Meyer eds., 2009), available at http:// www.cisg.law.pace.edu/cisg/biblio/el-saghir.html [emphasis added].

83. Id. (stating that Egyptian commentators reject application of the CISG to barter because of the 
Article 1702 of the French Civil Code defines an "exchange" as "a contract by which the parties give to each other one thing for another," ${ }^{\prime 4}$ the Frenchderived Louisiana Civil Code strengthens the distinction between sales and exchanges by defining "exchange" as "a contract, by which the parties to the contract give to one another, one thing for another, whatever it be, except money; for in that case it would be a sale." ${ }^{\circ 5}$

In the interest of fairness, the author of this paper is an American trained to understand the law of commercial transactions in goods through the lens of the U.C.C. and applying the reciprocal contract doctrine thus feels natural to him. Commentators trained in different legal traditions could argue for or against the applicability of the CISG to barter based on their home legal traditions until they are blue in the face without making any headway towards a consensus. To avoid this problem, this paper examines the merits of applying the CISG to barter transactions for the purpose of promoting uniformity in international trade.

\section{Applying the CISG to Barter Transactions Benefits International Trade and the Global Economy}

The preamble to the CISG points to the establishment of a new economic order based on the mutual economic benefit of global trade. ${ }^{86}$ Further, it acknowledges that global trade plays a key role in developing friendly relations between states. ${ }^{87}$ It concludes that uniform laws governing international trade are essential to achieving these goals. ${ }^{88}$

This need for uniformity extends to barter transactions. Because of the complexity of such transactions, especially when conducted across international borders, it is beneficial for the parties to be able to rely on uniform law. That said, since acceptance of the application of the CISG to barter is far from widespread, it would be prudent for parties to specify an alternate source of law in their drafting in case the court refuses to apply the CISG. ${ }^{89}$

way they view it against their home legal culture).

84. C. CIV. art. 1702 (Fr.).

85. LA. Civ. Code AnN. art. 2660 (2010), available at http://www.legis.state.la.us/lss/toc.htm [emphasis added].

86. United Nations Convention on Contracts for the International Sale of Goods preamble, U.N. Doc. A/CONF.97/18, Annex 1 (Apr. 11, 1980).

87. Id.

88. Id.

89. Susan J. Martin-Davidson, Selling Goods Internationally: Scope of the U.N. Convention on 


\section{The Historical Perspective}

According to the 1978 UNCITRAL note, exchange transactions occur more frequently in the international arena than they do domestically because of their importance in easing foreign exchange difficulties. ${ }^{90}$ At the time that UNCITRAL was studying this issue, barter was common in international transactions involving countries with non-market economies. ${ }^{91}$ For example, in 1970 Yugoslav Airlines contracted to pay approximately one sixth of the \$35 million price of seven McDonnell-Douglas jetliners in Yugoslav products including hams, glassware, textiles and jewelry. ${ }^{92}$ As was common, the reason for this barter transaction was twofold: first and foremost, the Yugoslavs had limited foreign currency to spend and their domestic currencies were not readily convertible. ${ }^{93}$ Secondly, they wanted to boost their exports. ${ }^{94}$

\section{Barter Remains Common in International Trade Involving Developing Nations}

Since the collapse of the Soviet Union, international barter has become much less common. Yet, it continues to be an important means of global trade, especially in transactions with parties from developing nations. An example of this is the barter transactions involving grain that many developing countries engaged in during the 2008 spike in grain prices. ${ }^{95}$ When countries placed restrictions on the export of grain in order to protect domestic supplies, they turned to barter in order to trade their grain with other countries. ${ }^{96}$ These government-to-government contracts bypassed the export restrictions, ${ }^{97}$ enabling the parties to trade goods they had surpluses of for goods they had shortages of without subjecting themselves to the aberrations of the global

\footnotetext{
Contracts for the International Sale of Goods, 17 Мich. Sт. J. INT'L. L. 657, 696 (2009).

90. See Note by the Secretariat, supra note 1, at 191.

91. Morgan, supra note 3.

92. Id.

93. Id.

94. Id.

95. See Sue Kirchhoff \& John Waggoner, Global Demand Lifts Grain Prices, Gobbles Supplies, USA ToDAy, Feb. 12, 2008, at 1B. Global grain prices more than doubled in some cases due to increased demand for biofuel production.

96. Javier Blas, Nations in Secret Deals over Grain Supplies, Fin. Times (London), Apr. 11, 1008, at 9 .

97. $I d$.
} 
commodities market. For example, in March, 2008, Egypt agreed to trade rice to Syria in exchange for wheat $;{ }^{98}$ in October, 2008, Thailand agreed to barter rice to Iran for Oil $;{ }^{99}$ and as of January, 2009, countries including Russia, Malaysia, Vietnam and Morocco had signed or were negotiating such deals for commodities ranging from rice to vegetable oil. ${ }^{100}$

Economists with the United Nations' Food and Agriculture Organization believe that this type of government-to-government bartering is likely to become more common due not only to food shortages, but because of the difficulty of obtaining credit and shortages in countries' foreign currency reserves. ${ }^{101}$ The cost of trade credit, which finances goods while in transit, has spiked sixfold since the recent financial crisis. ${ }^{102}$ Thus, for many of the same reasons, Soviet bloc nations engaged in barter, the current financial crisis has pushed developing nations to do the same.

Furthermore, barter is commonplace in doing business with nations facing international sanctions. In addition, enabling parties to circumvent the sanctions, barter solves a common dilemma facing countries under sanction: that they have the capacity to produce valuable goods, but since they are unable to sell them for money, they have very limited stores of foreign currency with which to make purchases.

This is not always as easy as it sounds. China and the Democratic Republic of Congo (hereinafter "DRC") finalized a deal in April, 2008 by which China would develop billions of dollars of infrastructure in the DRC in exchange for millions of tons of copper and cobalt. ${ }^{103}$ While this was a means for China to procure much needed raw materials and the DRC to get infrastructure it could not afford otherwise, it also appears to have been intended to circumvent issues with the DRC's debt to western lenders. ${ }^{104}$ Particularly, officials from international lending institutions warned that any deal resulting in the DRC acquiring new debt would scuttle ongoing

98. $I d$.

99. Javier Blas \& Tim Johnston, Thais to Barter Rice for Oil with Iran, Fin. TimEs (London, Asia Edition), Oct. 28, 2008, at 6.

100. Javier Blas, Nations Barter for Food amid Credit Crisis, Fin. Times (London), Jan. 27, 2009, at 8 .

101. Blas \& Johnston, supra note 99.

102. Alan Beattie, Policymakers Strive to Explain Plunge in Trade, Fin. Times (London, Asia Edition), Mar. 9, 2009, at 2.

103. William Wallis, Congo Outlines $\$ 9 b n$ China Deal, Fin. Times (London, Asia Edition), May 10, 2008 , at 4.

104. Id. 
negotiations for a write-off of the DRC's debt. ${ }^{105}$ In order to secure debt relief, the DRC was later forced to reduce the size of the China deal by three billion dollars. ${ }^{106}$

In Myanmar, the ruling junta purchased two billion dollars of military equipment from China, largely through barter ${ }^{107}$ While China largely ignores the international sanctions against Myanmar, ${ }^{108}$ this arrangement enabled the cash-starved junta to purchase equipment that they would not have otherwise been able to afford. Similarly, barter is a means for businesses in countries facing sanctions to do business with outsiders despite the lack of trade financing. For example, Iranian businessmen trade textiles, stones and petrochemical products to Korean and Chinese parties in exchange for raw materials. ${ }^{109}$ Countries facing sanctions are not only bartering goods; Cuba has resorted to bartering people, in the form of the 30,000 medical personnel it sent to Venezuela in exchange for 90,000 daily barrels of oil. ${ }^{110}$

While these barter deals are a means of circumventing international law, there is some benefit because it can allow these countries to procure the goods they need to sustain their populations without giving them money to purchase weapons or line the pockets of corrupt despots. More importantly, they demonstrate that barter deals still occur frequently in the international arena, justifying the need for the application of the CISG to barter.

\section{The Future Need to Apply the CISG to Barter Transactions}

Beyond barter deals between developing nations, we must be prepared for the possibility that international barter will become more widespread at some point in the future. In the event of a sudden global economic change, it is possible that we could see parties in developed nations engaging in barter across international borders virtually overnight. If this were to happen, it would be imperative to have a uniform legal framework to govern these transactions and the CISG is well suited for this purpose.

105. Id.

106. Barney Jopson, Congo to Get Debt Relief, Fin. Times (London), Feb. 26, 2010, available at http://www.ft.com/cms/s/0/d0e4e8b4-222c-11df-9a72-00144feab49a.html.

107. Myanmar Keeps the Wheels On With China's Help-Trade With Beijing Mitigates Sanctions and Nourishes Junta, WALL ST. J., Jan. 24, 2008, at A10.

108. Id.

109. Roula Khalaf \& Najmeh Bozorgmehr, Solitary Shore, Fin. TimEs (London, Asia Edition), Feb. 13, 2009, at 7. at MM44.

110. Roger Cohen, The End of the End of the Revolution, N.Y. TimEs, Dec. 5, 2008, Late Edition, 
We have already seen this occur at the domestic level in the United States. Faced with a shortage of credit and excess inventories following the fall 2008 financial meltdown, many Americans turned to barter. ${ }^{111}$ Use of barter networks ${ }^{112}$ skyrocketed and in the San Francisco Bay Area, barter listings on Craigslist.org increased by twenty five percent since the start of the current recession. ${ }^{113}$ Were an analogous situation to develop involving international barter, having uniform law would make these transactions more predictable and less costly. Since we already have an international framework in the CISG that can effectively govern barter, it only makes sense that it should be applied to barter transactions.

111. Richard C. Paddock, Despite Economic Hardships, New Buying Power, N.Y. Times, Nov. 29, 2009 , at $35 \mathrm{~A}$.

112. Barter networks, such as International Monetary Systems allow participating businesses to accept proprietary "trade dollars" from their customers as payment in lieu of official currency. They then use the trade dollars to purchase goods and services from other members.

113. Paddock, supra note 111. 